\title{
Inhibition of K99 Antigen Synthesis by L-Alanine Enterotoxigenic Escherichia coli
}

\author{
By J. P. GIRARDEAU, ${ }^{*}$ H. C. DUBOURGUIER AND Ph. GOUET \\ Laboratoire de Microbiologie, Centre de Recherches Zootechniques et Vétérinaires, I.N.R.A. \\ Theix - 63110 Beaumont, France
}

(Received 20 January 1981; revised 9 June 1981)

The effect of various culture media on K99 antigen production by enterotoxigenic Escherichia coli strains of bovine origin was investigated by slide agglutination tests, enzyme-linked immunosorbent assays and in vitro attachment to intestinal villi. L-Alanine at concentrations higher than $0.7 \mathrm{~g} \mathrm{l}^{-1}$ was responsible for the inhibition of $\mathrm{K} 99$ synthesis observed on media rich in amino acids. The increased inhibitory activity of L-alanine in glucose-rich media after autoclaving suggested the formation of inhibitory products via Maillard's reaction. Of various L-alanine derivatives tested, only those that hydrolysed to L-alanine were inhibitory. L-Alanine analogues were without effect and the addition of 10 mM-cyclic AMP did not overcome the repression of K99 biosynthesis by L-alanine. Enzymes involved in cell wall synthesis such as L-alanine racemase or D-alanyl-D-alanine synthetase were evidently unaffected by L-alanine.

\section{INTRODUCTION}

Many enterotoxigenic Escherichia coli strains of bovine origin possess K99 antigen, responsible for the attachment of bacterial cells to intestinal epithelium (Ørskov et al., 1975; Moon et al., 1976; Morin et al., 1976; Dubourguier et al., 1978). This proteinaceous, filamentous structure, which is coded for by a plasmid, is not expressed at $18^{\circ} \mathrm{C}$ and its detection is generally difficult after culture on rich media (nutrient broth, MacConkey agar, deoxycholate agar), which are therefore unsuitable for use in serological diagnosis. According to Guinée et al. (1976), these difficulties may be due either to masking of K99 antigen by the abundant capsular $\mathrm{K}$ antigens, or to catabolic repression by glucose. Guinée et al. (1976) developed the semi-synthetic Minca medium which resulted in improved detection of K 99 and proved particularly useful for the cultivation of organisms for slide agglutination tests.

We found that neither K99 synthesis nor its detection were sensitive to high concentrations of Casamino acids and glucose in culture media sterilized by filtration rather than autoclaving (unpublished observation). Recently we reported the inhibitory effect of L-alanine and its derivatives on K99 synthesis (Girardeau et al., 1979). The present paper identifies the inhibitors of $\mathrm{K} 99$ synthesis among the culture medium components and examines the effects of sterilization by filtration or autoclaving on their inhibitory activity.

\section{METHODS}

Escherichia coli strains and media. Strains B41 (0101:K99), B44 (09:K30:K99) and K $12: \mathrm{K} 99:$ Nal $^{\mathrm{r}}$ were obtained from Dr. R. Sellwood (Institute for Research on Animal Diseases, Compton, Newbury, Berks., U.K.). Strain 86a (0101:K30:K99) was isolated from diarrhoeic calves.

Strains were grown at $37^{\circ} \mathrm{C}$ for 15 or $24 \mathrm{~h}$ in liquid Minca medium (Guinée et al., 1976) or on moist slopes of Minca medium solidified with $2 \%(\mathrm{w} / \mathrm{v})$ agar. We investigated K99 production in the presence of D-glucose, 
L-alanine (both from Merck), D-alanine, $\beta$-alanine, $N$-methyl-DL-alanine, L-alanine ethyl ester, $N$-acetyl-L-alanine, $N$-methyl-L-alanine, $\beta$-aminobutyrate, $\alpha$-aminoisobutyrate, L- $\alpha$-aminobutyrate, L-alanylglycine and L-alanylL-alanine (all from Sigma); each of these compounds was added to Minca medium at various concentrations ranging from 0.25 to $4 \mathrm{~g}^{-1}$ before autoclaving, or added to autoclaved Minca medium by sterile filtration. Likewise, the antibiotics Albizine (ICN Pharmaceuticals, Cleveland, Ohio, U.S.A.), L-alanosine (Gruppo le Petit, Milan, Italy) and DL-lanthionine (Sigma) were added to Minca medium at final concentrations of 1, 10, 25, 50, and $100 \mu \mathrm{g} \mathrm{ml}^{-1}$. Cyclic AMP was added at 5 or $10 \mathrm{mM}$ in Minca medium with $\mathrm{L}$-alanine $\left(1 \mathrm{~g}^{-1}\right)$.

Strains were also grown on G20 media (Raibaud et al., 1966) which contained (per litre): peptone (Evans), $15 \mathrm{~g}$; yeast extract, $10 \mathrm{~g}$; tryptose (Difco), $10 \mathrm{~g}$; glucose, $20 \mathrm{~g}$; agar, $10 \mathrm{~g}$. The medium was buffered at $\mathrm{pH} 7.6$ and autoclaved for $20 \mathrm{~min}$ at $118^{\circ} \mathrm{C}$. Strains were also grown on a Minca medium to which the different G20 components were added. Peptone, yeast extract and tryptose were added alone or in combination with glucose (at the same final concentration as in G20) to liquid or solid Minca medium. These components were either added to Minca medium before autoclaving, or added to autoclaved Minca medium by sterile filtration, to avoid Maillard's reaction (Maillard, 1912). In the same manner, the 17 amino acids contained in Casamino acids (Difco) were added to the Minca medium either separately, or in combination with glucose to give a final concentration of $4 \mathrm{~g}$ $\mathrm{I}^{-1}$; the additions were made before autoclaving or by sterile filtration. Each amino acid was prepared in buffered solution so as to obtain a final $\mathrm{pH}$ of $7 \cdot 5$.

$K 99$ antiserum. Rabbit and sheep antisera against K99 antigen were prepared (Sojka, 1965) using E. coli strains $\mathrm{B} 41, \mathrm{~B} 44$ and $\mathrm{K} 12: \mathrm{K} 99: \mathrm{Nal}^{\mathrm{r}}$ grown at $37^{\circ} \mathrm{C}$. Antiserum to cationic $\mathrm{K} 99$ was obtained either by absorbing $\mathrm{K} 12: \mathrm{K} 99: \mathrm{Nal}^{\mathrm{r}}$ antiserum with $\mathrm{K} 12: \mathrm{Nal}^{\mathrm{r}}$ grown at $37^{\circ} \mathrm{C}$, or by absorbing $\mathrm{B} 41$ antiserum with strain $\mathrm{B} 41$ grown at $18^{\circ} \mathrm{C}$ [at $18^{\circ} \mathrm{C}$ strain $\mathrm{B} 41$ did not express the anionic form of $\mathrm{K} 99$ (Morris et al., 1978)]. The antiserum was then made monospecific by absorption with a B41 mutant anionic strain deficient in cationic K 99 (obtained from Dr J. Morris, Central Veterinary Laboratory, Weybridge, Surrey, U.K.).

Enzyme-linked immunosorbent assay (ELISA) for K99. The amount of K99 antigen in cell suspensions was estimated by an ELISA technique. The bacterial suspension was adjusted to an $A_{620}$ of 0.4 , corresponding to approximately $5 \times 10^{8}$ bacteria $\mathrm{ml}^{-1}$.

The globulin fraction was precipitated from rabbit anti-cationic K99 serum with ammonium sulphate at $50 \%$ saturation (Ellens et al., 1979). The wells of polystyrene microtitration plates (Cooke) were coated by incubation $\left(18 \mathrm{~h}\right.$ at $37^{\circ} \mathrm{C}$ ) with $50 \mu \mathrm{l}$ of the rabbit globulin fraction diluted $1 / 500$ in $0.05 \mathrm{M}$-sodium carbonate buffer $\mathrm{pH}$ 9.6. The plates were then rinsed four times with PBS $\left(\mathrm{NaCl}, 0.14 \mathrm{M} ; \mathrm{KH}_{2} \mathrm{PO}_{4}, 0.0015 \mathrm{M} ; \mathrm{Na}_{2} \mathrm{HPO}_{4}, 0.016 \mathrm{M} ; \mathrm{KCl}\right.$, $0.003 \mathrm{M}$ ) containing $0.05 \%(\mathrm{v} / \mathrm{v})$ Tween 80 (PBS Tween), and incubated for $2.5 \mathrm{~h}$ at $37^{\circ} \mathrm{C}$ with $50 \mu \mathrm{l}$ of serially diluted bacterial suspension in each well. Plates were then washed four times with PBS Tween and incubated again for $2.5 \mathrm{~h}$ at $37^{\circ} \mathrm{C}$ after the addition to each well of $50 \mu \mathrm{l}$ sheep anti-K99 globulin fraction, obtained in a manner similar to the rabbit globulin fraction. After four rinses with PBS Tween, $50 \mu$ conjugated horseradish peroxidase rabbit anti-sheep IgG (Nordic Immunological Laboratories) diluted 1/500 in carbonate buffer was added to each well and the plates were incubated for $1.5 \mathrm{~h}$ at $37^{\circ} \mathrm{C}$. Incubation was followed by five rinses with PBS Tween and addition of $50 \mu \mathrm{l}$ of the enzyme substrate. The substrate mixture contained: $o$-phenylenediamine, $40 \mathrm{mg}$; hydrogen peroxide $30 \%(\mathrm{v} / \mathrm{v}), 40 \mu \mathrm{l}$; phosphate/citrate buffer $\left(0.05 \mathrm{M}\right.$-citric acid/0.1 M-Na $\left.\mathrm{HPO}_{4}\right) \mathrm{pH} 5.0,100 \mathrm{ml}$. After 15 min, the reaction was terminated by addition of $50 \mu \mathrm{l} 0.5 \mathrm{M}-\mathrm{NaOH}$. The highest dilution that still showed maximum colour was taken as the titre. The colour intensity was either estimated visually or determined as the $A_{494}$ (Eppendorf photometer $1110 \mathrm{M}$ ) in a $1 / 16$ dilution.

Slide agglutination test and in vitro attachment. The presence of $\mathrm{K} 99$ antigen was shown by the slide agglutination test with specific cationic K99 antiserum diluted 1/10. In vitro attachment tests were also performed and quantified as previously described (Girardeau, 1980). The maximum attachment index of 100 represents an average of 30 bacterial cells attached over a $50 \mu \mathrm{m}$ length of brush border.

Haemagglutination tests. Direct haemagglutination tests were performed in microtitration plates with equal volumes $(25 \mu \mathrm{l})$ of $1 \%(\mathrm{v} / \mathrm{v})$ sheep red blood cells and of dilutions of bacterial suspension, in the presence of $0.5 \%$ (w/v) D-mannose (Jones \& Rutter, 1974). Plates were incubated at $4{ }^{\circ} \mathrm{C}$ and examined after 1 or $2 \mathrm{~h}$. The highest dilution of antigen that gave complete agglutination was defined as one haemagglutination unit (h.u.).

Preparation of partially purified $K 99$ antigen. K99 antigen was extracted from $E$. coli strains B41, B44 and 86a grown in Roux flasks for $15 \mathrm{~h}$ at $37^{\circ} \mathrm{C}$ on solid Minca medium with or without the addition of L-alanine $\left(2 \mathrm{~g} \mathrm{l}^{-1}\right)$. The K99 antigen was isolated by a simplified method similar to that used to isolate K88 antigen (Stirm et al., 1967). Briefly, bacteria were harvested in PBS pH 7.2 by shaking gently at $60^{\circ} \mathrm{C}$ for 15 min, and centrifuged at $27000 \mathrm{~g}$ for $10 \mathrm{~min}$. The K99 antigen was recovered from the supernatant by centrifugation at $110000 \mathrm{~g}$ for 200 min, and then redissolved in $0.1 \mathrm{M}-\mathrm{PBS} \mathrm{pH} \mathrm{7.2}$. This preparation will be referred to as UC 110 .

Immunoelectrophoresis and gel double diffusion techniques. Immunoelectrophoresis was performed in Noble agar (Scheidegger, 1955) using $0.05 \mathrm{M}$-veronal/HCl buffer $\mathrm{pH} 8.2$ and staining with amido black. Agar double diffusion (Ouchterlony) tests were performed in $0.9 \%(\mathrm{w} / \mathrm{v})$ agarose (Merck) in $0.05 \mathrm{M}$-veronal/ $\mathrm{HCl}$ buffer $\mathrm{pH}$ 8.2. As the K 99 antigen diffused very slowly, it was added to the wells $20 \mathrm{~h}$ before the antibody. 


\section{RES U L T S}

Effect of autoclaving $G 20$ medium on the inhibition of $K 99$ synthesis. When $E$. coli strains $\mathrm{B} 41, \mathrm{~B} 44$ and $86 \mathrm{a}$ were cultured for $18 \mathrm{~h}$ at $37^{\circ} \mathrm{C}$ on $\mathrm{G} 20$ medium, long bacilli $(5 \mu \mathrm{m})$ were obtained. In contrast, Minca medium gave shorter forms. The negative results for slide agglutination tests and the lack of in vitro attachment (Table 1) showed that K99 synthesis had been inhibited on autoclaved G20 medium. After sterilization by autoclaving or filtration, Minca medium was supplemented with G20 components, either alone or in combination, in order to determine their effect on K99 antigen synthesis (Table 1).

In the absence of glucose, the different G20 components either alone or in combination allowed K99 synthesis whatever the mode of sterilization. In the presence of glucose, K99 synthesis was unaffected when additives were filter-sterilized, but inhibited when they were sterilized by autoclaving (Table 1). We therefore attempted to isolate an active fraction from an autoclaved solution of peptone $\left(75 \mathrm{~g} \mathrm{l}^{-1}\right)$ and glucose $\left(100 \mathrm{~g} \mathrm{l}^{-1}\right)$ at $\mathrm{pH} \mathrm{8.0.} \mathrm{The} \mathrm{pH}$ was then adjusted by adding concentrated phosphoric acid and each precipitated fraction $(\mathrm{pH}$ $6 \cdot 5,5 \cdot 3,4.5$ and 3.0 fractions) was redissolved separately in $0.5 \mathrm{M}$-phosphate buffer $\mathrm{pH} 7.2$. Each of these four fractions, or the corresponding soluble fraction with a pH between 3.0 and $8 \cdot 0$, were added separately to Minca medium by sterile filtration. Their concentrations were adjusted to reproduce the initial G20 composition. None of the precipitated fractions inhibited K99 synthesis; inhibitory activity was found only in the soluble fraction. Moreover, when the peptone/glucose mixture was autoclaved and dialysed for $3 \mathrm{~d}$ against phosphate buffer, it completely lost its inhibitory activity.

Inhibition of $\mathrm{K} 99$ synthesis by an autoclaved mixture of Casamino acids and glucose. Liquid or solid Minca medium was supplemented with Casamino acids/glucose solution

\section{Table 1. Effect of culture medium composition and sterilization procedure on K99 production} by $E$. coli strains $B 41$ and $B 44$

The bacteria were grown on G20 medium and on Minca medium supplemented with components of G20 medium and/or with Casamino acids, at the following final concentrations (per litre): peptone, $15 \mathrm{~g}$; tryptose, $10 \mathrm{~g}$; yeast extract, $10 \mathrm{~g}$; glucose, $20 \mathrm{~g}$; Casamino acids, $25 \mathrm{~g}$. The results were very similar for the two strains; means are shown.

\begin{tabular}{|c|c|c|c|c|c|c|c|}
\hline \multirow[b]{3}{*}{$\begin{array}{l}\text { Basal } \\
\text { medium }\end{array}$} & \multirow[b]{3}{*}{ Additions } & \multicolumn{6}{|c|}{ K99 production in medium with components: } \\
\hline & & \multicolumn{3}{|c|}{ Sterilized by filtration } & \multicolumn{3}{|c|}{ Sterilized by autoclaving } \\
\hline & & $\begin{array}{l}\text { Slide agglu- } \\
\text { tination* }\end{array}$ & Attachment $\dagger^{\dagger}$ & h.u. $\neq$ & $\begin{array}{l}\text { Slide agglu- } \\
\text { tination* }\end{array}$ & Attachment ${ }^{\dagger}$ & h.u. $\neq$ \\
\hline G20 & None & + & ND & ND & - & 0 & 8 \\
\hline $\begin{array}{l}\text { Minca } \\
\text { (solid) }\end{array}$ & $\begin{array}{l}\text { Tryptose } \\
\text { Peptone } \\
\text { Yeast Extract }\end{array}$ & + & 95 & 256 & + & 90 & 256 \\
\hline $\begin{array}{l}\text { Minca } \\
\text { (solid) }\end{array}$ & $\begin{array}{l}\text { Tryptose } \\
\text { Peptone } \\
\text { Yeast Extract } \\
\text { Glucose }\end{array}$ & + & 95 & 256 & - & 0 & 16 \\
\hline $\begin{array}{l}\text { Minca } \\
\text { (liquid) }\end{array}$ & $\begin{array}{l}\text { Casamino acids + } \\
\text { Glucose }\end{array}$ & - & 0 & 16 & - & 0 & 16 \\
\hline $\begin{array}{l}\text { Minca } \\
\text { (solid) }\end{array}$ & $\begin{array}{l}\text { Casamino acids + } \\
\text { Glucose }\end{array}$ & + & 90 & 128 & - & 0 & 8 \\
\hline
\end{tabular}

$\mathrm{ND}$, Not done.

*, Agglutination with $1 / 10$ dilution of specific cationic $\mathrm{K} 99$ antiserum; -, no agglutination.

$\dagger$ In vitro attachment index (see Methods).

$\ddagger$ Haemagglutination units with sheep red blood cells. 
Table 2. Effect of addition of amino acids on K99 production by E. coli strains B4I and B44 grown in Minca medium

Each of the 17 amino acids contained in Casamino acids was added separately to Minca medium, to give a concentration of $4 \mathrm{~g} \mathrm{l}^{-1}$. The results shown are for strain $\mathrm{B} 41$ in autoclaved medium without simultaneous addition of glucose. Similar results were obtained with strain B44 and when the media were filter-sterilized and when glucose was added with the amino acids. For footnotes, see Table 1.

\begin{tabular}{|c|c|c|c|}
\hline \multirow[b]{2}{*}{ Amino acid added } & \multicolumn{3}{|c|}{ K99 production assessed by: } \\
\hline & Slide agglutination* & Attachment ${ }^{\dagger}$ & h.u. $\neq$ \\
\hline L-Alanine & - & 0 & 8 \\
\hline L-Threonine & + & 35 & ND \\
\hline $\left.\begin{array}{l}\text { L-Aspartate } \\
\text { L-Glutamate }\end{array}\right\}$ & ++ & 100 & 256 \\
\hline All other amino acids & + & $70-95$ & $128-256$ \\
\hline
\end{tabular}

sterilized either by filtration or autoclaving. Solid Minca medium supplemented with glucose $\left(20 \mathrm{~g} \mathrm{t}^{-1}\right)$ and Casamino acids $\left(25 \mathrm{~g} \mathrm{l}^{-1}\right)$ inhibited $\mathrm{K} 99$ synthesis in autoclaved but not filter-sterilized media; liquid Minca medium with the same supplement was inhibitory regardless of the sterilization method (Table 1).

Specific inhibition of K99 synthesis by L-alanine. The 17 amino acid constituents of Casamino acids were added to Minca medium alone or in combination with glucose after sterilization, either by filtration or autoclaving, and their inhibitory activity on K99 synthesis was determined (Table 2). The concentration of each amino acid was adjusted to $4 \mathrm{~g} \mathrm{I}^{-1}$ [approximately that found in $2.5 \%(\mathrm{w} / \mathrm{v})$ Casamino acids].

Addition of $\mathrm{L}$-alanine $\left(4 \mathrm{~g} \mathrm{l}^{-1}\right)$ to Minca medium after filter sterilization or autoclaving, both in the presence and absence of glucose, led to an inhibition of K99 synthesis. L-Threonine $\left(4 \mathrm{~g} \mathrm{l}^{-1}\right)$ led to morphological alterations (Fig. 1) analogous to those induced by $\beta$-lactamines; $E$. coli B41 was particularly sensitive to this effect. The culture became viscous and clear, suggesting bacterial lysis. We observed a number of lysed cells, which could still adhere to the intestinal villi. The slide agglutination reaction was affected by the viscosity of the medium but was always positive. L-Glutamate and L-aspartate $\left(4 \mathrm{~g} \mathrm{l}^{-1}\right)$ increased $\mathrm{K} 99$ synthesis. The other 13 amino acids tested were without effect on K99 synthesis.

Effect of L-alanine concentration on $K 99$ production. $\mathrm{K} 99$ production by strain B41 grown either on Minca medium, or on Minca medium supplemented with Casamino acids $\left(3 \mathrm{~g}^{-1}\right)$, both supplemented with various concentrations of L-alanine, was investigated by slide agglutination, attachment and ELISA (Table 3).

L-Alanine at concentrations in Minca medium in excess of $0.36 \mathrm{~g} \mathrm{l}^{-1}$ decreased $\mathrm{K} 99$ production, as assessed by ELISA and attachment assays, by more than $50 \%$; it completely inhibited synthesis at concentrations greater than $0.7 \mathrm{~g}^{-1}(8 \mathrm{mM})$. Inhibitory activity of $\mathrm{L}$-alanine assessed by the ELISA method and by in vitro attachment gave similar results (Table 3). In contrast, the slide agglutination test was still positive with $0.7 \mathrm{~g} \mathrm{~L}$-alanine $\mathrm{1}^{-1}$; this test was apparently a more sensitive assay for K99. For cells grown on Minca medium supplemented with $3 \mathrm{~g}$ Casamino acids $1^{-1}$, the $\mathrm{L}$-alanine effect was less pronounced and did not lead to complete inhibition of K99 synthesis, as evidenced by positive slide agglutination tests (results not shown).

Inhibitory effect of filter-sterilized or autoclaved L-alanine alone or in association with glucose. The results in Table 1 show that the inhibition of $\mathrm{K} 99$ synthesis appeared only after autoclaving the glucose solution with peptone or Casamino acids, suggesting that Maillard-type 'browning' reactions are involved in this inhibitory effect (Maillard, 1912). We therefore added to Minca medium filter-sterilized or autoclaved L-alanine alone, or a mixture 


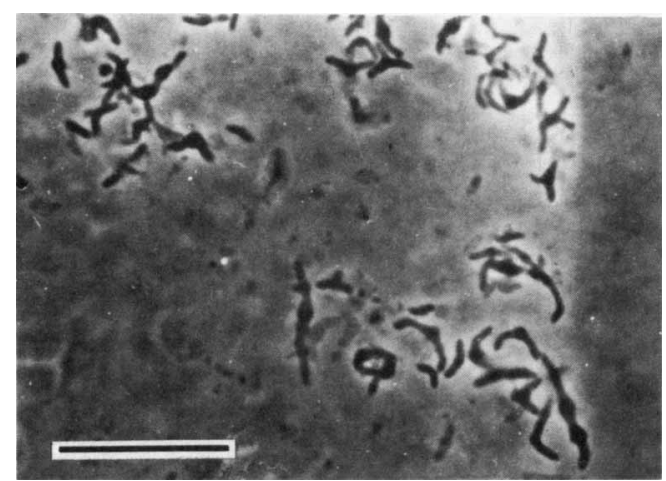

Fig. 1. Altered morphology of $E$. coli $\mathrm{B} 41$ grown on Minca medium supplemented with L-threonine $(4 \mathrm{~g}$ $\left.1^{-1}\right)$. The bar marker represents $10 \mu \mathrm{m}$.

Table 3. Effect of $\mathrm{L}$-alanine addition on $\mathrm{K} 99$ production by E. coli strain B4I grown in Minca medium

Inhibition of $\mathrm{K} 99$ production assessed by:

\begin{tabular}{|c|c|c|c|c|c|c|}
\hline \multirow[b]{2}{*}{$\begin{array}{c}\text { Concn of } \\
\text { L-alanine } \\
\left(\mathrm{g} \mathrm{l}^{-1}\right)\end{array}$} & \multicolumn{3}{|c|}{ In vitro attachment } & \multicolumn{3}{|c|}{ ELISA } \\
\hline & $\begin{array}{c}\text { Slide } \\
\text { agglutination* }\end{array}$ & $\begin{array}{l}\text { No. of bacteria } \\
\text { per } 50 \mu \mathrm{m} \\
\text { brush border }\end{array}$ & $\begin{array}{c}\text { Inhibition } \\
(\%)\end{array}$ & $\begin{array}{l}\text { Last } \\
\text { positive } \\
\text { dilution }\end{array}$ & $A_{494}$ & $\begin{array}{c}\text { Inhibition } \\
(\%)\end{array}$ \\
\hline 0 & +++ & 26 & 0 & 256 & 460 & 0 \\
\hline 0.24 & $++t$ & 15 & 43 & 64 & ND & ND \\
\hline 0.36 & ++ & 12 & 53 & 32 & 210 & 55 \\
\hline 0.47 & + & $4 \cdot 3$ & 83 & 32 & 110 & 76 \\
\hline 0.71 & \pm & 0.53 & 98 & 8 & 80 & 82 \\
\hline 1.43 & - & 0 & 100 & 8 & 30 & 82 \\
\hline $2 \cdot 15$ & - & 0 & 100 & 4 & 50 & 90 \\
\hline $4 \cdot 30$ & - & 0 & 100 & 1 & 0 & 100 \\
\hline
\end{tabular}

ND, Not done.

* Agglutination test with $1 / 10$ dilution of specific K99 cationic antiserum, scored from no agglutination (-) to strong agglutination $(+++)$.

of $\mathrm{L}$-alanine and glucose $[2.5 \%(\mathrm{w} / \mathrm{v})$ each in the initial solution]. The final concentration of $\mathrm{L}$-alanine in the culture medium ranged from 0.14 to $1.4 \mathrm{~g} \mathrm{l}^{-1}$.

Attachment inhibition rose with increasing concentrations of $\mathrm{L}$-alanine alone up to $0.7 \mathrm{~g}$ $1^{-1}$, above which the K99 antigen could not be detected by any technique (Fig. 2). Adding a mixture of $\mathrm{L}$-alanine and glucose sterilized by autoclaving induced a decrease in attachment similar to that of $\mathrm{L}$-alanine alone: inhibition was complete above $0.7 \mathrm{~g} \mathrm{l}^{-1}$. However, the same mixture sterilized by filtration caused less inhibition, although attachment was decreased $63 \%$ with $1.4 \mathrm{~g} \mathrm{~L}$-alanine $\mathrm{1}^{-1}$. K99 antigen was still detected by the slide agglutination test even with $1.4 \mathrm{~g} \mathrm{~L}$-alanine $1^{-1}$ in the medium.

Immunoelectrophoresis of extracts of E. coli strains B41 and 86 a grown on Minca medium and Minca medium supplemented with L-alanine. UC 110 preparations from strains $\mathrm{B} 41$ and $86 \mathrm{a}$ grown on Minca medium with or without L-alanine at $2 \mathrm{~g}^{-1}$ (see Methods) were tested against B41 and 86a antisera, and against specific cationic K99 antiserum. UC 110 preparations of strains B41 and 86a grown on Minca medium both showed only a cathodic 


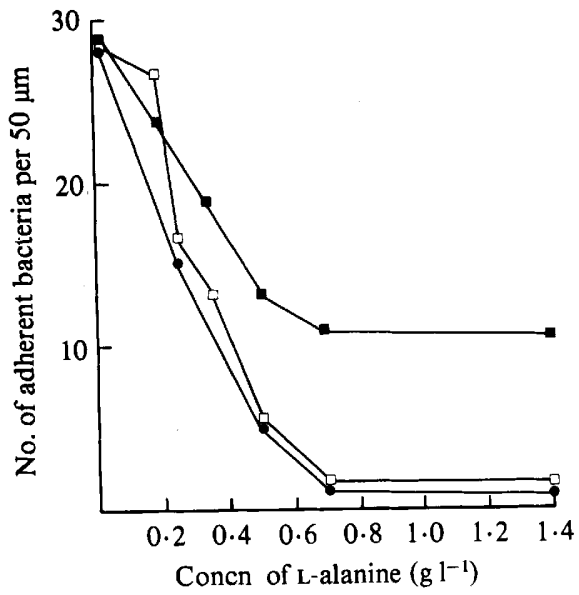

Fig. 2. Effect of L-alanine on in vitro attachment of $E$. coli B41 to $50 \mu \mathrm{m}$ lengths of calf intestinal brush border. The bacteria were grown on Minca medium plus L-alanine ( $)$, plus L-alanine and glucose (filter-sterilized) $(\square)$, or plus L-alanine and glucose (autoclaved) ( $\square$ ).

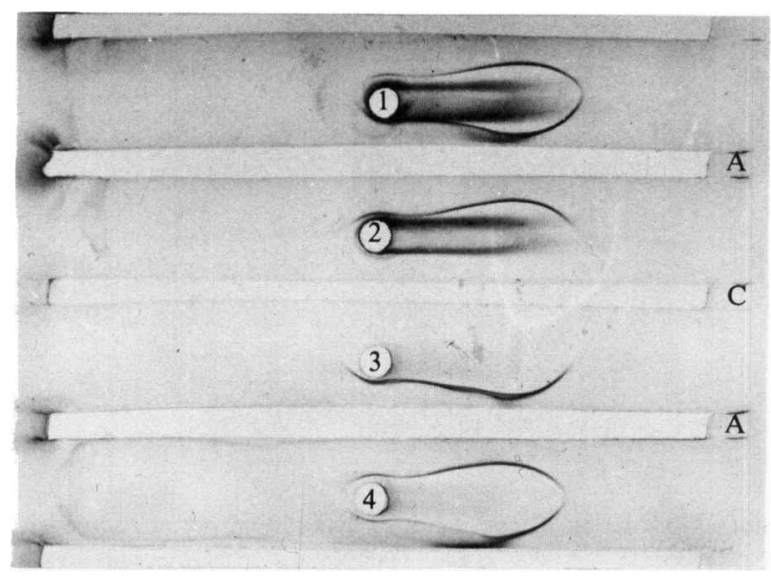

Fig. 3. Immunoelectrophoresis of an extract of $E$. coli B41 grown on Minca medium (wells 1 and 2) or on Minca medium plus L-alanine $\left(2 \mathrm{~g}^{-1}\right)$ (wells 3 and 4) against B41 antiserum (A) and against specific $\mathrm{K} 99$ antiserum prepared as described in Methods (C).

line against specific cationic K99 antiserum, characteristic of K99 antigen. With B41 and 86a antisera, a second cathodic line appeared, which might represent the $\mathrm{O}$ antigen extracted at $60^{\circ} \mathrm{C}$ (not inactivated at $100^{\circ} \mathrm{C}$ for $30 \mathrm{~min}$ ). With UC 110 preparations from cells grown in Minca medium with $2 \mathrm{~g} \mathrm{~L}$-alanine $\mathrm{l}^{-1}$, the $\mathrm{K} 99$ cathodic line never appeared, although the $\mathrm{O}$ antigen line was observed (Fig. 3). The behaviour of the K99 antigen from cells grown on Minca medium and on Minca medium plus L-alanine was identical in double diffusion tests (not shown). However, the immunodiffusion pattern of K99 extract run against the two specific K99 antisera showed clearly that the serum absorbed with bacterial cells grown with L-alanine (single line of immunoprecipitate) was more specific than that absorbed by bacterial cells grown at $18^{\circ} \mathrm{C}$ on Minca medium (double line).

The inhibitory effect of L-alanine on $\mathrm{K} 99$ synthesis at $37^{\circ} \mathrm{C}$ was exploited to prepare absorbed antisera against homologous strains. Specific cationic K99 antiserum was prepared from $\mathrm{K} 12: \mathrm{K} 99: \mathrm{Nal}^{\mathrm{r}}$ antiserum absorbed with $\mathrm{K} 12: \mathrm{K} 99: \mathrm{Nal}^{\mathrm{r}}$ cells grown at $37^{\circ} \mathrm{C}$ on 
Minca medium plus $0.2 \%(\mathrm{w} / \mathrm{v}) \mathrm{L}$-alanine. In immunoelectrophoresis experiments, the $\mathrm{O}$ antigen line never appeared, but the K99 cathodic line was always present, confirming the inhibition of $\mathrm{K} 99$ synthesis in the presence of L-alanine.

Effect of $\mathrm{L}$-alanine derivatives and related metabolites on the appearance of $K 99$ in strains $B 41, B 44$ and $86 a$. Derivatives of $\mathrm{L}$-alanine or related metabolites were added to Minca medium at concentrations ranging from 0.25 to $4 \mathrm{~g} \mathrm{l}^{-1}$ and their effect on K99 production was determined.

As already shown L-alanine was inhibitory at concentrations above $0.7 \mathrm{~g} \mathrm{l}^{-1}$ (8 mM). D-Alanine was without effect, as were $N$-acetyl or $N$-methyl derivatives of alanine. L-Alanine ethyl ester had an activity similar to L-alanine, probably due to its hydrolysis by the bacterial cells. The dipeptide L-alanylglycine, which on hydrolysis yields half its weight as L-alanine, was active above $2 \mathrm{~g} \mathrm{l}^{-1}$. The dipeptide $\mathrm{L}$-alanyl-L-alanine was slightly more inhibitory than $\mathrm{L}$-alanine, but $\beta$-alanine and other molecules whose stereochemical structures are close to L-alanine, such as L- $\alpha$-aminobutyrate, had no effect on K99 synthesis. Compounds in the metabolic pathway of L-alanine, such as pyruvate, oxoglutarate and L-glutamate had no inhibitory activity. Addition of cyclic AMP at 5 or $10 \mathrm{mM}$ did not overcome the inhibition of $\mathrm{K} 99$ due to L-alanine at $1 \mathrm{~g}^{-1}$.

Effect on K99 synthesis of antibiotics acting as analogues to L-alanine or active in L-alanine-dependent biosynthetic pathways. D-Cycloserine, a competitive inhibitor of alanine racemase (Strominger et al., 1959) which has a 100 -fold higher affinity for the enzyme than that of L-alanine, did not inhibit $\mathrm{K} 99$ synthesis at $20 \mu \mathrm{g} \mathrm{ml}^{-1}$, nor did albizine and L-alanosine (analogues of L-alanine). DL-Lanthionine, a thio amino acid (Ala-S-Ala) which is not hydrolysed by bacteria, did not inhibit $\mathrm{K} 99$ synthesis at $100 \mu \mathrm{g} \mathrm{m} \mathrm{m}^{-1}$. Penicillin $\mathrm{G}$ and ampicillin affect the biosynthesis of cell walls by inhibiting D-alanine carboxypeptidase. With these antibiotics at $25 \mu \mathrm{g} \mathrm{ml}^{-1}$, poor growth of strain B41 occurred but $\mathrm{K} 99$ synthesis was not inhibited and the bacteria retained their attachment properties.

\section{DISCUSSION}

The inhibition of $\mathrm{K} 99$ biosynthesis in protein-rich media appears to be due to the presence of L-alanine. Greater than $80 \%$ inhibition, as assessed by ELISA and attachment assays, was obtained with L-alanine at $0.7 \mathrm{~g} \mathrm{l}^{-1}(8 \mathrm{mM})$ : the concentration of $\mathrm{L}$-alanine in $\mathrm{G} 20$ medium was $0.3 \mathrm{~g} \mathrm{l}^{-1}$.

However, in G20 medium, which also contained a large amount of glucose $\left(20 \mathrm{~g} \mathrm{l}^{-1}\right)$, the inhibition of K99 synthesis only occurred after heating or autoclaving. This could be due to the formation, by Maillard reactions during autoclaving, of condensation compounds more active than L-alanine alone, or by the decrease in the concentration of free glucose as a result of such reactions. The inhibitory activity observed on media containing concentrations of L-alanine lower than $0.7 \mathrm{~g}^{-1}$ suggested that an L-alanine-glucose condensation product appearing in Maillard's reaction has greater inhibitory activity than L-alanine. On the other hand, the presence of free glucose in filter-sterilized media could account for the lack of inhibition by L-alanine in these media. Indeed, a high concentration of glucose would allow a high metabolic rate with rapid protein synthesis, which would decrease the concentrations of free amino acids. The concentration of $\mathrm{L}$-alanine would rapidly be decreased below an inhibitory level and K99 synthesis would then occur.

The derivatives and analogues of L-alanine tested are not inhibitors of K99 synthesis. Albizine and alanosine did not suppress K99 synthesis, although their antibiotic activity is due to their structural similarity to L-alanine, with which they compete. Another mechanism which might relate to L-alanine inhibition is the competitive inhibition between L-alanine and D-cycloserine on the activities of alanine racemase and D-alanyl-D-alanine synthetase, both of which are involved in cell wall synthesis. However, this mechanism does not appear to be involved. 
Inhibition does not appear to be related to catabolite pathways as reported by Isaacson (1980). Pyruvate and 2-oxoglutarate did not repress K99 synthesis in strains B41 and B44. Moreover, since inhibition by L-alanine was not overcome by addition of cyclic AMP ( 5 or 10 $\mathrm{mM})$, it is evidently not subject to cyclic AMP-dependent catabolite repression.

In conclusion, the decrease in inhibitory effect by glucose and amino acids may be due to specific mechanisms of cell permeability which decrease the entry of L-alanine into the bacteria. The inhibitory effect of L-alanine, which seems to depend on stereochemical structure, may also involve either enzyme repression in K99 biosynthesis or inhibition of plasmid expression. Further information is therefore required.

\section{REFERENCES}

Dubourguier, H. C., Gouet, Ph., Contrepois, M. \& GiRARDEAU, J. P. (1978). Diarrhée du veau nouveau-né: propriétés et mécanisme d'action des $E$. coli entéropathogènes chez le veau et le porcelet. Annales de recherches vétérinaires 9, 129-152.

Ellens, D. J., De Leeuw, P. W. \& Rozemond, H. (1979). Detection of the K99 antigen of Escherichia coli in calf faeces by enzyme-linked immunosorbent assay (ELISA). Veterinary Quarterly 1, 169-175.

GIRARDEAU, J. P. (1980). A new in vitro technique for attachment to intestinal villi using enteropathogenic E. coli. Annales de l'Institut Pasteur 131B, 31-37.

Girardeau, J. P., Dubourguier, H. C. \& Gouet, PH. (1979). Facteurs intervenant dans la biosynthèse de l'antigène d'attachement K99 et médiateurs moléculaires de l'attachement aux villosités intestinales. In Microbiologie 1979. Bactéries et protistes. (Colloque C.N.R.S., Orsay, 28-30 May 1979), pp. 152-153.

Guinee, P. A. M., Jansen, W. H. \& Agterberg, C. (1976). Detection of the K99 antigen by means of agglutination and immunoelectrophoresis in $E$. coli isolates from calves and its correlation with enterotoxigenicity. Infection and Immunity 13, 13691377.

ISAACSON, R. E. (1980). Factors affecting expression of the Escherichia coli pilus K99. Infection and Immunity 28, 190-194.

Jones, G. W. \& RuTTER, J. M. (1974). The association of $\mathrm{K} 88$ antigen with haemagglutinating activity in porcine strains of $E$. coli. Journal of General Microbiology 84, 135-144.

Maillard, L. C. (1912). Actions des acides aminés sur les sucres; formation des mélanoïdines par voie méthodiques. Compte rendu de l'Académie des Sciences 154, 66-70.

Moon, H. W., Whipp, S. C. \& Skartvedt, S. M. (1976). Etiologic diagnosis of diarrheal diseases of calves. Frequency and methods for detecting enterotoxin and $\mathrm{K} 99$ antigen production by $E$. coli. American Journal of Veterinary Research 37, 1025-1029.

Morin, M., Lariviere, S. \& Lallier, R. (1976). Pathological and microbiologic observations made on spontaneous cases of acute neonatal calf diarrhoea. Canadian Journal of Comparative Medicine 40, 228-240.

Morris, J. A., Stevens, A. E. \& Sojka, W. H. (1978). Anionic and cationic components of the K99 surface antigen from Escherichia coli B41. Journal of General Microbiology 107, 173-175.

ØRSKOv, I., ØRSKOv, E., SMITH, H. W. \& SoJKA, W. J. (1975). The establishment of K99, a thermolabile, transmissible Escherichia coli antigen, previously called "Kco" possessed by calf and lamb enteropathogenic strains. Acta pathologica et microbiologica scandinavica 83, 31-36.

Raibaud, P., Dickinson, A. B., Sacquet, E., Charlier, H. \& Mocquot, G. (1966). La microflore du tube digestif du rat. Technique d'étude et milieux de culture proposés. Annales de l'Institut Pasteur 110, 568-590.

SCHEIDEgGER, J. J. (1955). Une micro méthode d'immuno-électrophorèse. International Archives of Allergy and Applied Immunology 7, 103-110.

SoJKA, W. J. (1965). Escherichia coli in domestic animals and poultry. Review, Commonwealth Agricultural Bureaux No. 7, 205-214.

STIRM, S., ØRSkov, F., ØRSKov, I. \& MANSA, B. (1967). Episome-carried surface antigen K88 of Escherichia coli. II. Isolation and chemical analysis. Journal of Bacteriology 93, 731-739.

Strominger, J. L., ThrenN, R. H. \& Scott, S. S. (1959). Antagonism by D-alanine of uridine nucleotide accumulation induced by oxamycin. Journal of the American Chemical Society 81, 3803-3804. 